\title{
Hydrodynamic changes of the soil-cactus interface, effective actual evapotranspiration and its water efficiency under irrigation
}

José E. F. de Morais ${ }^{1}$, Thieres G. F. da Silva², Maria G. de Queiroz ${ }^{3}$, Gherman G. L. de Araujo ${ }^{4}$, Magna S. B. Moura ${ }^{4} \&$ George do N. Araújo Júnior ${ }^{2}$

${ }^{1}$ Universidade Federal Rural de Pernambuco/Departamento de Engenharia Agrícola. Recife, PE. E-mail: joseedson50@hotmail.com (Corresponding author)

${ }^{2}$ Universidade Federal Rural de Pernambuco/Unidade Acadêmica de Serra Talhada. Serra Talhada, PE. E-mail: thieres_freire@yahoo.com.br; georgejunior_91@hotmail.com

${ }^{3}$ Universidade Federal de Viçosa/Departamento de Engenharia Agrícola. Viçosa, MG. E-mail: mg.gabi@hotmail.com

${ }^{4}$ Embrapa Semiárido. Petrolina, PE. E-mail: ghermangarcia@hotmail.com; magna.moura@embrapa.br

Key words:

water retained in the plant soil water balance

cactus

modelling

\begin{abstract}
A B S T R A C T
The knowledge on soil water dynamics is the basis of crop water management. The soil water balance (SWB) method is used for this purpose. However, its application in cactus may lead to misinterpretation in water efficiency analysis, since it does not consider the amount of water retained in the plant (WRP). This study aimed to evaluate SWB applicability, hydrodynamic changes and water efficiency of forage cactus clones under irrigation. The clones 'Orelha de Elefante Mexicana' (OEM), 'IPA Sertânia' (IPA) and 'Miúda' (MIU) were submitted to irrigation depths (2.5, 5.0 and $7.5 \mathrm{~mm}$ ) and frequencies (7, 14 and 28 days), in Serra Talhada, PE, Brazil, between March 2012 and August 2013. The SWB was applied, by adding the WRP in the estimate of the effective actual evapotranspiration $\left(\mathrm{ETr}_{\mathrm{EF}}\right)$. The water efficiency indicators were calculated. The actual evapotranspiration on $\mathrm{SWB}\left(\mathrm{ETr}_{\mathrm{SWB}}\right)$ overestimated $\mathrm{ETr}_{\mathrm{EF}}$ and, like other SWB components, it was affected by the factors irrigation depth, frequency and clone. The clone OEM is the most efficient, due to the use of the WRP, while MIU leads to highest gross economic returns for sale of cladodes as seed. As conclusion, the application of the soil water balance method in areas cultivated with cactus species must be accompanied by WRP.
\end{abstract}

\section{Palavras-chave:}

água retida na planta balanço de água no solo cactáceas modelagem

\section{Alterações hidrodinâmicas da interface solo-palma, evapotranspiração real efetiva e sua eficiência hídrica sob irrigação}

\section{R E S U M O}

$\mathrm{O}$ conhecimento da dinâmica de água no solo subsidia o manejo hídrico na lavoura. $\mathrm{O}$ método do balanço de água no solo (BAS) é usado para este fim, porém sua aplicação em cultivos de cactáceas pode promover interpretação errônea na análise da eficiência hídrica uma vez que não considera a quantidade de água retida na planta (ARP). Objetivou-se avaliar a aplicabilidade do balanço de água no solo, as alterações hidrodinâmicas e eficiência hídrica em cultivos de palma forrageira irrigada. Os clones Orelha de Elefante Mexicana (OEM), IPA Sertânia e Miúda (MIU) foram submetidos às lâminas $(2,5 ; 5,0$ e 7,5 mm) e frequências de irrigação (7, 14 e 28 dias), em Serra Talhada, PE, entre março de 2012 e agosto de 2013. O BAS foi aplicado adicionando-se a ARP na estimativa da evapotranspiração real efetiva $\left(\mathrm{ETr}_{\mathrm{FF}}\right)$. Indicadores de eficiência hídrica foram calculados. A evapotranspiração real baseada no BAFS $\left(E \operatorname{Tr}_{\mathrm{BAS}}\right)$ superestimou a $\mathrm{ETr}_{\mathrm{FF}}$ e semelhante a outros componentes do BAS, foi afetada pelos fatores lâmina-frequência-clone. O clone OEM é o mais eficiente em razão do uso da ARP enquanto o MIU é o que promove maior retorno econômico bruto de venda dos cladódios para semente. Conclui-se que a aplicação do método do balanço de água no solo cultivado com espécies cactáceas deve ser acompanhada da ARP. 


\section{INTRODUCTION}

Despite its complexity, the soil water balance (SWB) has satisfactory results in the analysis of water dynamics in the cultivation of C3 and C4 plants (Ghiberto et al., 2011; Evett et al., 2012). However, in cactus species, such as forage cactus, which has high moisture content in the cladodes (85 to $90 \%$ ), the SWB method may lead to misinterpretation in the estimate of the actual crop evapotranspiration (ETr), since it does not consider the amount of water retained by the plant (WRP), which occurs particularly in the parenchyma aquifer and in the large vacuoles (Taiz \& Zeiger, 2009).

The water depth transferred through the biosphereatmosphere interface can be called "effective actual evapotranspiration" $\left(\mathrm{ETr}_{\mathrm{EF}}\right)$, resulting from the difference between the ETr of the SWB method ( $\left.\mathrm{ETr}_{\text {sWB }}\right)$ and the WRP, as proposed in the present study. The $\mathrm{ETr}_{\mathrm{EF}}$ varies among forage cactus clones due to their morphological differences (Silva et al., 2015a), which alter the capacity of water accumulation in the canopy and, consequently, water use efficiency (Pinheiro et al., 2014; Silva et al., 2015b).

The knowledge on forage cactus $\mathrm{ETr}_{\mathrm{EF}}$ will allow a better understanding about the process of water transfer to the atmosphere and will refine the analysis of water use efficiency, i.e., of the capacity of conversion of water into biomass production and the economic water productivity, which represents the gross profitability, both as a function of crop evapotranspiration (Pereira et al., 2012).

Water use efficiency indicators allow to analyze the productive response of the plants in order to identify favorable cultivation conditions. In addition, they assist in the selection of cultivars more tolerant to water stress, in water management and in the analysis of effectiveness of irrigation systems (Araya et al., 2011; Pereira et al., 2012).

Thus, this study aimed to evaluate the applicability of soil water balance, hydrodynamic alterations and water efficiency in irrigated cultivation of forage cactus.

\section{Material AND Methods}

The experiment was carried out in an area of forage cactus cultivation (7 56’ 20" S; 38 17' 31" W; 498 m), in Serra Talhada-PE, Brazil, located in the mesoregion of Middle Pajeú river, in the Brazilian semi-arid region.

The reference evapotranspiration in the experimental period was $2,872.8 \mathrm{~mm}\left(5.23 \mathrm{~mm} \mathrm{~d}^{-1}\right)$, while rainfall was 469 $\mathrm{mm}$ (equivalent to $327 \mathrm{~mm}$ year-1 ${ }^{-1}$, which is below the historic mean $\left(657 \mathrm{~mm}\right.$ year $\left.{ }^{-1}\right)$. The soil of the area was classified as Red Yellow Argisol with bulk density of $1.5 \mathrm{~kg} \mathrm{dm}^{-3}$, total porosity of $40.4 \%, 692.1 \mathrm{~g} \mathrm{~kg}^{-1}$ of sand, $249.2 \mathrm{~g} \mathrm{~kg}^{-1}$ of silt and $58.8 \mathrm{~g}$ $\mathrm{kg}^{-1}$ of clay.

The studied clones were 'Orelha de Elefante Mexicana'/ IPA-200016 (Opuntia stricta (haw.) Haw.), 'IPA Sertânia'/IPA200205 (Nopalea cochenillifera (L.) Salm-Dyck) and 'Miúda'/ IPA-100004 (Nopalea cochenillifera (L.) Salm-Dyck), which are resistant to Dactylopius opuntiae.

The clones were planted in February 2010 after plowing and harrowing, followed by nitrogen fertilization with $130 \mathrm{~kg} \mathrm{ha}^{-1}$ of urea and organic fertilization using bovine manure (3000 $\left.\mathrm{kg} \mathrm{ha}^{-1}\right)$. The spacing was $1.6 \times 0.2 \mathrm{~m}(31,250$ plants ha-1) with $50 \%$ of the cladodes buried in the soil.

During the first biennial (two years) cycle, the crop was conducted under rainfed conditions, with the first cut in February 2012 (686 days after planting - DAP), maintaining only the basal cladode. From this moment on, the experimental period started, the irrigation system was installed and chemical fertilization with NPK (14-0-18, 16S) was monthly applied.

The study lasted for 524 days (18 months), from March 2012 to August 2013, with application of minimum cultivation practices.

The clones were arranged in a randomized block design $(\mathrm{RBD})$, with three replicates in split-split-plot scheme $(3 \times 3 \times$ $3+3$ ) and irrigated by a drip system (flow rate of $1.25 \mathrm{~L} \mathrm{~h}^{-1}$ at pressure of $100 \mathrm{kPa}$ ) with different water depths and intervals of water replacement.

The water depths $(2.5,5.0$ and $7.5 \mathrm{~mm})$ composed the plots, the intervals of water replacement in the soil $(7,14$ and 28 days) composed the subplots and the three clones composed the sub-subplots. Beside the experimental blocks, nine plots (three per clone) were installed for the conduction under rainfed conditions. These frequencies were defined based on information of forage cactus areas in Rio Grande do Norte, which received irrigation depths of $5.0 \mathrm{~mm}$ every 14 days, through a pressurized drip system.

The area was divided into 90 sub-subplots, each one containing four rows with 20 plants each one occupying an area of $25.6 \mathrm{~m}^{2}$, with an evaluation area of $12.8 \mathrm{~m}^{2}$.

The differentiation of irrigation depths (L) and frequencies (F) started on August 30, 2012. Maintenance water depths had been applied since March 2012, totaling $135 \mathrm{~mm}$, to maintain the uniformity of the stand.

The irrigation depths received by the clones were: $\mathrm{L}_{2.5}-\mathrm{F}_{7}=$ $552 \mathrm{~mm}$ year ${ }^{-1} ; \mathrm{L}_{2.5}-\mathrm{F}_{14}=501 \mathrm{~mm}$ year $^{-1} ; \mathrm{L}_{2.5}-\mathrm{F}_{28}=478 \mathrm{~mm}$ year ${ }^{-1}$; $\mathrm{L}_{5.0}-\mathrm{F}_{7}=641 \mathrm{~mm}$ year $^{-1} ; \mathrm{L}_{5.0}-\mathrm{F}_{14}=546 \mathrm{~mm}$ year $^{-1} ; \mathrm{L}_{5.0}-\mathrm{F}_{28}=499$ mm year ${ }^{-1} ; \mathrm{L}_{7.5}-\mathrm{F}_{7}=727 \mathrm{~mm}$ year $^{-1} ; \mathrm{L}_{7.5}-\mathrm{F}_{14}=589 \mathrm{~mm}$ year ${ }^{-1}$; $\mathrm{L}_{7.5}-\mathrm{F}_{28}=520 \mathrm{~mm}$ year ${ }^{-1}+$ rainfed condition $\left(471 \mathrm{~mm}\right.$ year $\left.{ }^{-1}\right)$.

In May 2012, 90 access tubes (one per sub-subplot) were installed at depth of $0.90 \mathrm{~m}$ and distance of $0.10 \mathrm{~m}$ from the plant rows, to measure the water content every $0.10 \mathrm{~m}$ using a capacitive sensor (Diviner@ 2000 ${ }^{\circledR}$, Sentek Pty Ltda., Australia), locally calibrated (Primo et al., 2015). These measurements started on June 1, 2012.

The data of water content and physical-hydraulic properties of the soil, described by Silva et al. (2015b), were used to calculate the actual evapotranspiration through the residual of the soil water balance $\left(\mathrm{ETr}_{\mathrm{SWB}}\right.$, in $\left.\mathrm{mm}\right)$, performed in intervals of 14 days, for a volume corresponding to $0.60 \mathrm{~m}$ of depth:

$$
-\mathrm{ETr}_{\mathrm{SWB}}=\mathrm{P}+\mathrm{I}-\mathrm{R} \pm \mathrm{Q}_{\mathrm{Z}} \pm \Delta \mathrm{S}_{\mathrm{Z}}
$$

where:

$\mathrm{P} \quad$ - rainfall, $\mathrm{mm}$;

I - irrigation, $\mathrm{mm}$;

$\mathrm{Q}_{\mathrm{z}} \quad$ - upward flow (capillary rise, CR) or downward flow (deep drainage, DD), $\mathrm{mm}$; and,

$\Delta S_{z}$ - variation in soil water storage in a control volume, $\mathrm{mm}$ 
$\mathrm{P}$ was obtained through an AWS (automatic weather station), which belongs to the Water and Climate Agency of Pernambuco, installed $200 \mathrm{~m}$ away from the experimental area.

I represented the treatments of irrigation depths and frequencies.

$\mathrm{Q}_{\mathrm{z}}$ through capillary rise or deep drainage was estimated using the equation of Darcy-Buckingham equation (Silva et al., 2014a), which requires the soil hydraulic conductivity and total water potential $(\mathrm{mm})$, obtained through the application of the instantaneous profile method (Primo et al., 2015).

$\Delta S$ was determined based on the difference between the values of soil water storage per layer at the end and beginning of the period of 14 days, provided by the capacitive probe.

The effective actual evapotranspiration $\left(\mathrm{ETr}_{\mathrm{EF}}\right)$ was calculated by the difference between $\mathrm{ETr}_{\mathrm{SWB}}$ and the water depth retained by the forage cactus (WRP):

$$
\mathrm{ETr}_{\mathrm{EF}}=\left(\mathrm{ET}_{\mathrm{SWB}}-\mathrm{WRP}\right)
$$

WRP was initially calculated with the data obtained at harvest (August 2013), to develop semi-empirical models as a function of the cladode area index (CAI):

$$
\mathrm{WRP}=(\mathrm{CGM}-\mathrm{CDM}) \times \mathrm{TNC} \times \mathrm{d}_{\text {water }}
$$

where:

WRP - water retained by the plant, in L;

CGM - individual cladode green mass, kg;

CDM - individual cladode dry mass, $\mathrm{kg}$;

TNC - total number of cladodes, units; and,

$\mathrm{d}_{\text {water }}$ - water density, $\mathrm{kg} \mathrm{L}^{-1}$.

Harvest was performed maintaining only the basal cladode. CGM and CDM were obtained based on the mean mass of 10 cladodes per sub-subplot. CDM was obtained after the cladodes were fragmented, placed in paper bags and taken to a forced-air oven at $65^{\circ} \mathrm{C}$ until constant weight.

TNC was recorded in interval of 30 days and at harvest, through biometric measurements. Besides TNC, the following variables were measured: plant canopy width $(\mathrm{PW}, \mathrm{cm})$, and length $(\mathrm{CL}, \mathrm{cm})$, width $(\mathrm{CW}, \mathrm{cm})$ and number $(\mathrm{CN}$, units) of cladodes per order of appearance $\left(\mathrm{CNi}\right.$, where $\mathrm{i}=1^{\text {st }}, 2^{\text {nd }}$ and $\mathrm{n}$ orders).

With the data of CL and CW, the cladode areas of 'IPA Sertânia', 'Miúda' and 'Orelha de Elefante Mexicana' were estimated based on the equations suggested by Silva et al. (2014b) and, later, the CAI $\left(\mathrm{m}^{2} \mathrm{~m}^{-2}\right)$, according to Pinheiro et al. (2014).

The relationships between WRP, in L, and CAI, in $\mathrm{m}^{2} \mathrm{~m}^{-2}$, for each one of the clones resulted in the models below, which explained 79\% ('IPA Sertânia', IPA), 83\% ('Miúda', MIU) and $85 \%$ ('Orelha de Elefante Mexicana', OEM) of the variation in WRP values.

$$
\begin{aligned}
& \mathrm{WRP}_{(\mathrm{IPA})}=8.5620 \times \mathrm{CAI}+1.1047 \\
& \mathrm{WRP}_{(\mathrm{MIU})}=5.5896 \times \mathrm{CAI}+0.7995
\end{aligned}
$$

$$
\mathrm{WRP}_{(\text {OЕM })}=4.4366 \times \mathrm{CAI}+1.4024
$$

The WRP values were converted to $\mathrm{mm}$, dividing the data by the area occupied by the plant $\left(\mathrm{AOP}\right.$, in $\left.\mathrm{m}^{2}\right)$, considering that the area of the plant is circular and that $\mathrm{PW}$ corresponds to the diameter of the circle:

$$
\mathrm{AOP}=\frac{\pi \times \mathrm{PW}^{2}}{4}
$$

The data of CAI and AOP of each biometric campaign and clone, and the DAC (days after cutting) were used to fit sigmoid models for the calculation of CAI, AOP and, thus, WRP over time, by applying their daily results in Eqs. 4, 5, 6 and 7. The difference between the WRP values of two consecutive days resulted in the daily WRP.

The data of $\mathrm{ETr}_{\mathrm{EF}}$ and yield of the clones in fresh matter $\left(\mathrm{Y}, \mathrm{kg} \mathrm{FM} \mathrm{ha}^{-1}\right)$ were used to estimate the water use efficiency (WUE, kg FM ha-1 $\mathrm{mm}^{-1}$ ) and economic water productivity (EWP, $\mathrm{R} \$ \mathrm{ha}^{-1} \mathrm{~mm}^{-1}$ ) (Araya et al., 2011):

$$
\mathrm{WUE}=\frac{\mathrm{Y}}{\sum \mathrm{ETr}_{\mathrm{EF}}}
$$

$$
\mathrm{EWP}=\frac{\mathrm{EG}}{\sum \mathrm{ETr}_{\mathrm{EF}}}
$$

where:

EG - economic gain per area unit, in $\mathrm{R} \$ \mathrm{ha}^{-1}$.

For EG, two situations were considered: the first one, the value paid per unit of cladode $\left(\mathrm{R} \$ 0.15\right.$ unit $\left.^{-1}\right)$, as suggested by the Agronomic Institute of Pernambuco, and the second one, the value paid per ton of green matter with net revenue of at least $10 \%\left(\mathrm{R} \$ 119 \mathrm{t}^{-1}\right.$ for IPA, $\mathrm{R} \$ 217 \mathrm{t}^{-1}$ for MIU and $\mathrm{R} \$ 140 \mathrm{t}^{-1}$ for OEM), based on the previously performed economic analysis. This analysis provided the net revenue and benefit/cost ratio of the forage cactus intended for sale as "forage" or "seed", according to the procedures described by Fernandes et al. (2008).

In the period from March to May 2012, when soil water balance was not made because the reading tubes were not installed yet, the $\mathrm{ETr}_{\mathrm{EF}}$ of forage cactus was obtained through the product between the ratio of $\mathrm{ETr}_{\mathrm{EF}} /$ Mean ETo of each treatment (June 2012 to August 2013) and the ETo (March to May 2012), as suggested by Silva et al. (2014a).

The data of $\mathrm{DD} / \mathrm{CR}, \triangle \mathrm{A}, \mathrm{ET}_{\mathrm{SWB}}$, WRP and $\mathrm{ET}_{\mathrm{EF}}$ WUE and EWP were subjected to the tests of normality and homoscedasticity and analysis of variance by $\mathrm{F}$ test. If significant and confirmed the interaction between the factors clones, irrigation depths and frequencies, the variables were subjected to the Fisher's LSD (Least significant difference) test of means at 0.05 probability level.

\section{Results AND Discussion}

The hydrodynamic components of the soil cultivated with forage cactus were affected by the irrigation depths, 
frequencies and clones and by the interaction of irrigation depth $\mathrm{x}$ frequency.

The vertical water flow in the soil occurred only in the form of deep drainage (DD) and was not altered by the irrigation depths and frequencies (Table 1), but only by the clones, with the highest magnitudes in the areas with the clones IPA and OEM.

The interaction of irrigation depth $\mathrm{x}$ frequency indicated that the DD was higher for the condition of $\mathrm{L}_{7.5}-\mathrm{F}_{14}$ (Table $2)$, which received the greatest water depth $\left(589 \mathrm{~mm}^{-1} \mathrm{mear}^{-1}\right)$, only inferior to the treatments $\mathrm{L}_{7.5}-\mathrm{F}_{7}\left(727 \mathrm{~mm}\right.$ year $\left.^{-1}\right)$ and $\mathrm{L}_{5.0}-\mathrm{F}_{7}\left(641 \mathrm{~mm}\right.$ year $\left.^{-1}\right)$. Under these conditions, the water consumption was more favored, reducing the downward flow of water, but in the first condition $\left(\mathrm{L}_{7.5}-\mathrm{F}_{14}\right)$ the reduction of water regime induced a sharp decrease in evapotranspiration, increasing the loss of water through DD.

Silva et al. (2015b) also observed differences in DD between these clones cultivated under rainfed conditions. In the present study, the DD accumulated during 15 months was $18.9 \mathrm{~mm}$, close to the mean of the rainfed condition $(18.6 \mathrm{~mm})$, which indicates that the irrigation depths and rainfalls were expressively low (Table 1).

The variation in soil water storage $(\Delta S)$, in turn, was not altered by either the irrigation depths and frequencies or the clones and their interactions ( $p>0.05$ ) (Tables 1 and 2), resulting in mean of $27.0 \mathrm{~mm}$. Silva et al. (2015b) also did not find differences between these clones. The $\Delta S$ is highly dependent on the applied amount of water, atmospheric demand, soil characteristics and water uptake capacity of the forage cactus roots (Primo et al., 2015).

The cumulative actual evapotranspiration of the forage cactus $\left(\mathrm{ETr}_{\mathrm{SWB}}\right)$ increased with the increment in irrigation depths and reduced with the increase in the interval of water replacement $(\mathrm{p}<0.05)$ (Table 1$)$. There was no difference of $\mathrm{ETr}_{\mathrm{SWB}}$ between the clones, although irrigated and with different morphophysiological characteristics. Silva et al. (2015b) observed similar trend for these same clones cultivated under rainfed conditions. The $\mathrm{L}_{75}-\mathrm{F}_{7}$ resulted in the highest values of $\operatorname{ETr}_{\text {SwB }}(765.9 \mathrm{~mm}$ ) (Table 2).

The $\mathrm{ETr}_{\mathrm{SWB}}$ of forage cactus was equal to $545.5 \mathrm{~mm}$ during 15 months ( $526 \mathrm{~mm}$ year ${ }^{-1}$ ), with daily mean of $1.45 \mathrm{~mm}$. This

Table 1. Isolated effects of irrigation depths (2.5; 5.0 and $7.5 \mathrm{~mm})$, and frequencies (7; 14 and 28 days) and clones of forage cactus ('IPA Sertânia', 'Miúda' and 'Orelha de Elefante Mexicana') on the hydrodynamic components of the soil

\begin{tabular}{|c|c|c|c|c|c|}
\hline \multirow{2}{*}{ Treatment } & \multicolumn{5}{|c|}{ Components of soil water balance (SWB) - mm } \\
\hline & $\mathrm{DD} / \mathrm{CR}$ & $\Delta \mathbf{S}$ & $\mathrm{ETr}_{\text {SWB }}$ & WRP & $\mathrm{ETr}_{\mathrm{EF}}$ \\
\hline $2.5 \mathrm{~mm}$ & $-14.8( \pm 20.7)$ & $27.3( \pm 2.3)$ & $-477.6( \pm 37.5) \mathrm{c}$ & $25.0( \pm 8.6) b$ & $-452( \pm 38.1) \mathrm{C}$ \\
\hline $5.0 \mathrm{~mm}$ & $-16.9( \pm 19.7)$ & $33.1( \pm 5.2)$ & $-547.3( \pm 93.3) b$ & $27.3( \pm 11.9) a b$ & $-519.9( \pm 93.7) b$ \\
\hline $7.5 \mathrm{~mm}$ & $-24.8( \pm 22.0)$ & $30.1( \pm 4.9)$ & $-611.5( \pm 118.1) \mathrm{a}$ & $31.0( \pm 5.6)$ a & $-580.6( \pm 116.7) \mathrm{a}$ \\
\hline 7 days & $-19.3( \pm 20.4)$ & $32.5( \pm 4.4)$ & $-648.9( \pm 110.8) \mathrm{a}$ & $28.5( \pm 10.4)$ & $-620.4( \pm 107.1) \mathrm{a}$ \\
\hline 14 days & $-26.0( \pm 25.7)$ & $29.6( \pm 5.8)$ & $-515.8( \pm 39.8) b$ & $27.1( \pm 8.1)$ & $-488.7( \pm 42.7) b$ \\
\hline 28 days & $-11.3( \pm 12.4)$ & $28.4( \pm 3.4)$ & $-471.7( \pm 33.9) \mathrm{C}$ & $27.6( \pm 9.7)$ & $-444.0( \pm 29.5) c$ \\
\hline Clone IPA & $-29.8( \pm 28.6) \mathrm{a}$ & $29.4( \pm 5.0)$ & $-647.7( \pm 106.9)$ & $33.3( \pm 7.5) \mathrm{a}$ & $-501.4( \pm 106.3)$ \\
\hline Clone MIU & $-8.7( \pm 9.9) b$ & $30.5( \pm 5.2)$ & $-672.6( \pm 101.9)$ & $31.4( \pm 6.1) \mathrm{a}$ & $-524.0( \pm 98.1)$ \\
\hline Clone OEM & $-17.9( \pm 13.6) a b$ & $30.6( \pm 4.6)$ & $-662.9( \pm 109.9)$ & $18.5( \pm 5.4) b$ & $-527.6( \pm 108.3)$ \\
\hline Mean & -18.9 & 30.2 & -545.5 & 27.8 & -517.7 \\
\hline Rainfed & -18.6 & 26.3 & -401.5 & 26.6 & -374.9 \\
\hline
\end{tabular}

DD - Deep drainage; CR - Capillary rise; $\Delta S$ - Variation in soil water storage;ETr Ir $_{\text {- Actual crop evapotranspiration; WRP - Water retained by the plant; ETr }}$ - Effective actual crop evapotranspiration; *Means followed by the same lowercase letters in the column do not differ statistically for the same irrigation depth, frequency or clone; **The data of DD were transformed by the Box Cox function and those of $\operatorname{ETr}_{\mathrm{EF}}$ by the function $1 / \mathrm{x}$, to meet the normality of residuals, but the actual data are presented

Table 2. Effects of the interaction of irrigation depths (2.5; 5.0 and $7.5 \mathrm{~mm}) \times$ frequencies (7; 14 and 28 days) on the hydrodynamics of the soil cultivated with clones of forage cactus

\begin{tabular}{|c|c|c|c|c|}
\hline \multirow{2}{*}{ Components } & \multirow{2}{*}{$\begin{array}{l}\text { Frequencies } \\
\text { (days) }\end{array}$} & \multicolumn{3}{|c|}{ Irrigation depths (mm) } \\
\hline & & 2.5 & 5.0 & 7.5 \\
\hline \multirow{4}{*}{$\mathrm{DD}(\mathrm{mm})$} & 7 & $-28.1( \pm 34.9)$ Aab & $-8.8( \pm 5.9) \mathrm{Bb}$ & $-20.9( \pm 11.7) \mathrm{ABa}$ \\
\hline & 14 & $-6.0( \pm 6.6) \mathrm{Bb}$ & $-24.2( \pm 29.8)$ Aab & $-47.9( \pm 19.9) \mathrm{Aa}$ \\
\hline & 28 & $-10.4( \pm 7.3) \mathrm{Ba}$ & $-17.8( \pm 20.4) \mathrm{ABa}$ & $-5.7( \pm 6.0) \mathrm{Ba}$ \\
\hline & Mean & -14.8 & -16.9 & -24.8 \\
\hline \multirow{4}{*}{$\Delta \mathrm{S}(\mathrm{mm})$} & 7 & $28.1( \pm 1.4)$ & $34.8( \pm 2.5)$ & $34.6( \pm 5.3)$ \\
\hline & 14 & $25.0( \pm 2.4)$ & $36.3( \pm 4.1)$ & $27.6( \pm 2.5)$ \\
\hline & 28 & $29.0( \pm 0.7)$ & $28.3( \pm 5.5)$ & $28.1( \pm 3.9)$ \\
\hline & Mean & 27.4 & 33.1 & 30.1 \\
\hline \multirow{4}{*}{$\mathrm{ETr}_{\mathrm{SWB}}(\mathrm{mm})$} & 7 & $-515.2( \pm 35.2)$ Ac & $-665.7( \pm 3.0) A b$ & $-765.9( \pm 7.5) \mathrm{Aa}$ \\
\hline & 14 & $-478.0( \pm 5.7) A b$ & $-511.5( \pm 33.0) \mathrm{Bb}$ & $-558.8( \pm 17.5) \mathrm{Ba}$ \\
\hline & 28 & $-439.5( \pm 7.9) \mathrm{Bb}$ & $-465.4( \pm 25.8) \mathrm{Cb}$ & $-510.2( \pm 6.2) \mathrm{Ca}$ \\
\hline & Mean & -477.6 & -547.3 & -611.5 \\
\hline \multirow{4}{*}{ WRP (mm) } & 7 & $23.6( \pm 8.9) \mathrm{Bb}$ & $28.3( \pm 16.0) \mathrm{ABab}$ & $33.6( \pm 4.7) \mathrm{Aa}$ \\
\hline & 14 & $30.3( \pm 11.2) \mathrm{Aa}$ & $23.5( \pm 8.1) \mathrm{Bb}$ & $27.6( \pm 5.9)$ Aab \\
\hline & 28 & $21.1( \pm 4.9) \mathrm{Cb}$ & $30.3( \pm 30.3) \mathrm{Aa}$ & $31.5( \pm 6.7) \mathrm{Aa}$ \\
\hline & Mean & 25.0 & 27.3 & 30.9 \\
\hline \multirow{4}{*}{$\mathrm{ETr}_{\mathrm{EF}}(\mathrm{mm})$} & 7 & $-491.6( \pm 38.1) A c$ & $-637.7( \pm 14.6) A b$ & $-732.2( \pm 11.6) \mathrm{Aa}$ \\
\hline & 14 & $-447.7( \pm 16.8) A B c$ & $-487.4( \pm 36.2)$ Bab & $-530.9( \pm 22.3) \mathrm{Ba}$ \\
\hline & 28 & $-418.4( \pm 2.9) \mathrm{Bb}$ & $-435.1( \pm 23.1) \mathrm{Cb}$ & $-478.7( \pm 6.3) \mathrm{Ca}$ \\
\hline & Mean & -452.6 & -520.1 & -580.3 \\
\hline
\end{tabular}

DD - Deep drainage; CR - Capillary rise; $\Delta S$ - Variation in soil water storage; $\operatorname{Tr}_{\mathrm{SWB}}$ - Actual crop evapotranspiration; WRP - Water retained by the plant; ETr ${ }_{\mathrm{EF}}-\mathrm{Effective} \mathrm{actual} \mathrm{crop}$ evapotranspiration; * Means followed by the same letters in the interaction of irrigation depth $\mathrm{x}$ frequency do not differ statistically 
A.

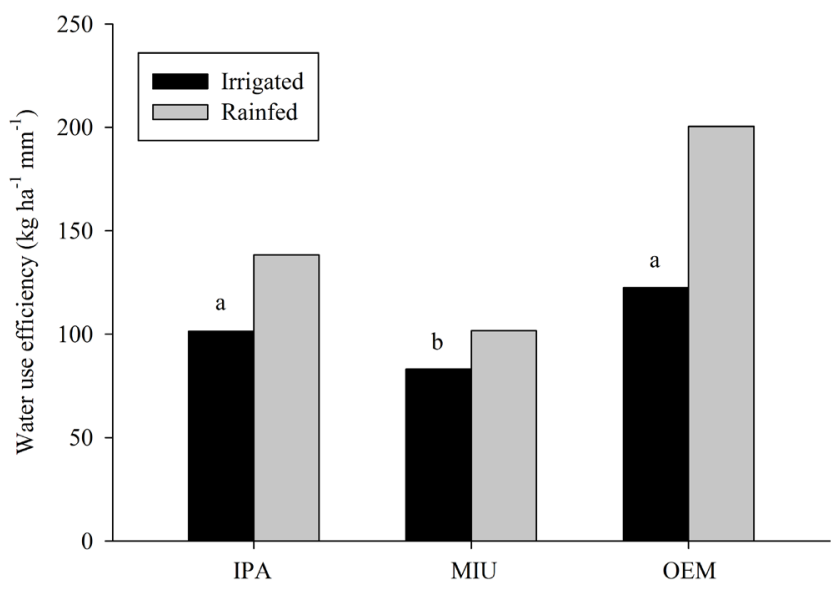

B.

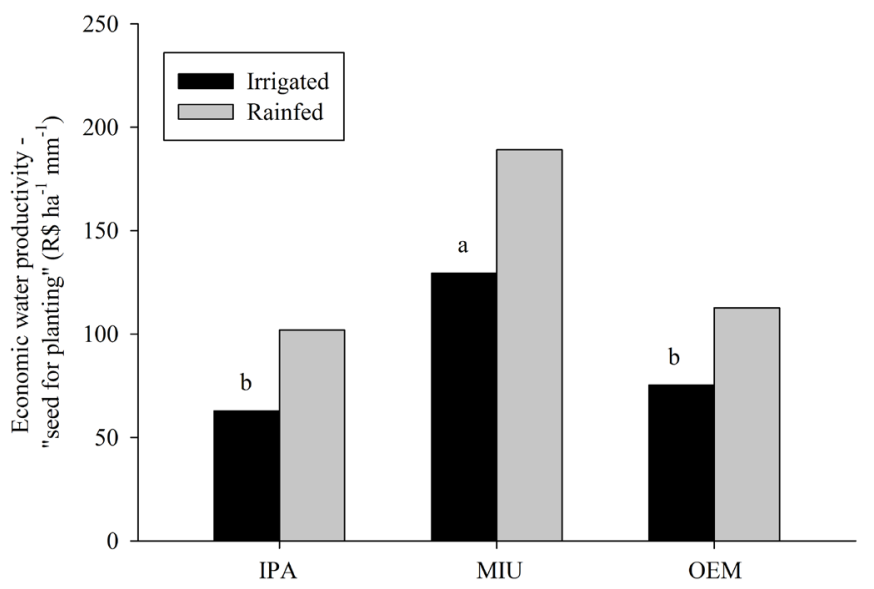

Means followed by the same letters do not differ statistically. The rainfed condition was not used in the statistical analysis, since the sub-subplots were arranged beside the experimental blocks Figure 1. Water use efficiency (A) and economic water productivity for cladodes intended for sale as "seed" (B) of forage cactus, 'IPA Sertânia' (IPA), 'Miúda' (MIU) and 'Orelha de Elefante Mexicana' (OEM)

value is inferior to that reported by Han \& Felker (1997) for Opuntia ellisiana L. (559 $\left.\mathrm{mm}_{\text {year }}{ }^{-1}, 1.53 \mathrm{~mm} \mathrm{~d}^{-1}\right)$, under rainfed conditions with rainfall of $662 \mathrm{~mm}^{-1} \mathrm{mear}^{-1}$, and by Consoli et al. (2013) in the Mediterranean of Sicily, Italy $\left(2.5 \mathrm{~mm} \mathrm{~d}^{-1}\right)$, with rainfall of $1,329.1 \mathrm{~mm}$.

The increment in irrigation depths increased the volume of water retained by the plant (WRP). The clones of the genus Nopalea showed higher water accumulation (Table 1), while the interaction $\mathrm{L}_{2.5}-\mathrm{F}_{28}$ promoted lower turgor in the cladodes $(21.1 \mathrm{~mm})$. The mean value of WRP was $27.8 \mathrm{~mm}$, close to that of the rainfed condition $(26.6 \mathrm{~mm})$.

The effective actual evapotranspiration $\left(\mathrm{ETr}_{\mathrm{EF}}\right)$, like $\mathrm{ETr}_{\mathrm{SWB}}$, increased with the increment in irrigation depths and frequencies (Table 1), reaching higher magnitudes in $\mathrm{L}_{7.5}-\mathrm{F}_{7}$ (Table 2). Although with similar trends, $\mathrm{ETr}_{\mathrm{EF}}$ and $\mathrm{ETr}_{\mathrm{SWB}}$ were different $(\mathrm{p}>0.05)$.

Hence, the application of the soil water balance method for cactus species, without the adoption of WRP may lead to misinterpretations about the evapotranspiration and in the evaluation of their water efficiency. The mean $\operatorname{ETr}_{\mathrm{EF}}$ was 518 $\mathrm{mm}$, with $1.37 \mathrm{~mm} \mathrm{~d}^{-1}$, which indicates overestimation of $5.4 \%$ in $\mathrm{ETr}_{\mathrm{SWB}}$, in relation to $\mathrm{ETr}_{\mathrm{EF}}$.

The values of $\mathrm{ETr}_{\mathrm{EF}}$ were used to obtain the water use efficiency (WUE) of $102 \mathrm{~kg} \mathrm{FM} \mathrm{ha}^{-1} \mathrm{~mm}^{-1}$. There was no effect of irrigation depths and frequencies, but of clones, with OEM and IPA exhibiting higher efficiency in comparison to MIU (Figure 1).

The WUE values obtained for irrigated forage cactus were lower than those for the rainfed condition, which received 471 $\mathrm{mm}$ year ${ }^{-1}$. These results indicate that the forage cactus is able to maintain the accumulation of dry matter in situations of reduction in water availability, although it decreases its water consumption. Therefore, the water retained in the cladodes ends up being a primordial factor for a high water use efficiency by the crop. Scalisi et al. (2016) claim that the water content in forage cactus suffers seasonality and, under water restriction, regulates the growth rate of the cladodes, justifying its high efficiency.

In this case, OEM was the clone that exhibited the lowest WRP, justifying the higher use of water and high efficiency of conversion into dry matter. Consoli et al. (2013) obtained WUE values of $44 \mathrm{~kg} \mathrm{ha}^{-1} \mathrm{~mm}^{-1}$ for Opuntia ficus-indica, with 16 months of age and receiving water depth of 1,010.7 mm year ${ }^{-1}$.

Like WUE, the economic water productivity (EWP) was not affected by the irrigation depths and frequencies $(p>0.05)$, but only by the clones in the sale of cladodes as "seed" (Figure 1B). The mean EWP for forage was $\mathrm{R} \$ 18 \mathrm{ha}^{-1} \mathrm{~mm}^{-1}$, indicating gross economic return of $\mathrm{R} \$ 18.00 \mathrm{ha}^{-1}$ for every $\mathrm{mm}^{-1}$ of $\mathrm{ETr}_{\mathrm{EF}}$

The EWP with yield intended for sale as "seed" (Figure 1) was superior for MIU ( $\left.\mathrm{R} \$ 122.1 \mathrm{ha}^{-1} \mathrm{~mm}^{-1}\right)$, compared with the clones OEM ( $\left.\$ 73.5 \mathrm{ha}^{-1} \mathrm{~mm}^{-1}\right)$ and IPA $\left(\mathrm{R} \$ 60.8 \mathrm{ha}^{-1} \mathrm{~mm}^{-1}\right)$. This result is due to the higher number of cladodes produced by this clone, as reported by Silva et al. (2015b). Under the rainfed condition, MIU obtained R $\$ 189.2 \mathrm{ha}^{-1} \mathrm{~mm}^{-1}$, OEM obtained $\mathrm{R} \$ 112.8 \mathrm{ha}^{-1} \mathrm{~mm}^{-1}$ and IPA, R\$ $101.1 \mathrm{ha}^{-1} \mathrm{~mm}^{-1}$.

\section{Conclusions}

1. The application of the soil water balance method in the cultivation of cactus species must be accompanied by the estimate of the water retained by the plant.

2. Most hydrodynamic components of the soil cultivated with forage cactus were altered by the irrigation depths and frequencies and type of clone.

3. Despite belonging to different genera (Nopalea and Opuntia), the clones of forage cactus, when irrigated, do not show differences in water consumption.

4. The clone of the genus Opuntia showed lower water accumulation in the cladodes, in comparison to the clones of the genus Nopalea.

5. The clone 'Miúda' showed higher gross economic return per evapotranspired water depth when the cladodes were intended for sale as "seed".

\section{ACKNOWLedgments}

To the Science and Technology Support Foundation of Pernambuco (FACEPE), for the financial support (APQ-0215$5.01 / 10)$ and for granting the scholarship. 


\section{Literature Cited}

Araya, A.; Stroosnijder, L.; Girmay, G.; Keesstra, S. D. Crop coefficient, yield response to water stress and water productivity of teff (Eragrostis tef (Zucc.). Agricultural Water Management, v.98, p.775-783, 2011. https://doi.org/10.1016/j.agwat.2010.12.001

Consoli, S.; Inglese, G.; Inglese, P. Determination of evapotranspiration and annual biomass productivity of a cactus pear (Opuntia ficusindica L. (Mill.) orchard in a Semi-arid Environment. Journal of Irrigation and Drainage Engineering, v.1, p.1-15, 2013.

Evett, S. R.; Schwartz, R. C.; Casanova, J. J.; Heng, L. K. Soil water sensing for water balance, ET and WUE. Agricultural Water Management, v.104, p.1-9, 2012. https://doi.org/10.1016/j.agwat.2011.12.002

Fernandes, A. L. T.; Santinato, R.; Fernandes, D. R. Irrigação na cultura do café. 2.ed. Uberaba: O Lutador, 2008. 476p.

Ghiberto, P. J.; Libardi, P. L.; Brito, A. S.; Trivelin, P. C. O. Components of the water balance in soil with sugarcane crops. Agricultural Water Management, v.102, p.1-7, 2011. https://doi.org/10.1016/j. agwat.2011.09.010

Han, H.; Felker, P. Field validation of water-use efficiency of the CAM plant Opuntia ellisiana in south Texas. Journal of Arid Environments, v.36, p.133-148, 1997. https://doi.org/10.1006/ jare.1996.0202

Pereira, L. S.; Cordery, I.; Iacovides, I. Improved indicators of water use performance and productivity for sustainable water conservation and saving. Agricultural Water Management, v.108, p.39-51. 2012. https://doi.org/10.1016/j.agwat.2011.08.022

Pinheiro, K. M.; Silva, T. G. F.; Carvalho, H. F. S.; Santos, J. E. O.; Morais, J. E. F.; Zolnier, S.; Santos, D. C. Correlações do índice de área do cladódio com características morfogênicas e produtivas da palma forrageira. Pesquisa Agropecuária Brasileira, v.49, p.939947, 2014. https://doi.org/10.1590/S0100-204X2014001200004
Primo, J. T. A.; Silva, T. G. F.; Siqueira e Silva, S. M.; Moura, M. S. B.; Souza, L. S. B. Calibração de sondas capacitivas, funções físicohídricas e variação do armazenamento de água em um Argissolo cultivado com palma forrageira. Revista Ceres, v.62, p.20-29, 2015. https://doi.org/10.1590/0034-737X201562010003

Scalisi, A.; Morandi, B.; Inglese, P.; Lo Bianco, R. Cladode growth dynamics in Opuntia ficus-indica under drought. Environmental and Experimental Botany, v.122, p.158-167, 2016. https://doi. org/10.1016/j.envexpbot.2015.10.003

Silva, T. G. F.; Miranda, K. R.; Santos, D. C.; Queiroz, M. G.; Silva, M. C.; Cruz Neto, J. F.; Araújo, J. E. M. Área do cladódio de clones de palma forrageira: Modelagem, análise e aplicabilidade. Revista Brasileira de Ciências Agrarias, v.9, p.633-641, 2014a. https://doi. org/10.5039/agraria.v9i4a4553

Silva, T. G. F.; Primo, J. T. A.; Morais, J. E. F.; Diniz, W. J. S.; Souza, C. A. A.; Silva, M. C. Crescimento e produtividade de clones de palma forrageira no semiárido e relações com variáveis meteorológicas. Revista Caatinga, v.28, p.10-18, $2015 \mathrm{a}$.

Silva, T. G. F.; Primo, J. T. A.; Moura, M. S. B.; Silva, S. M. S. e; Morais, J. E. F.; Pereira, P.C.; Souza, C.A.A. de. Soil water dynamics and evapotranspiration of forage cactus clones under rainfed conditions. Pesquisa Agropecuária Brasileira, v.50, p.515-525, 2015b. https://doi.org/10.1590/S0100-204X2015000700001

Silva, T. G. F.; Primo, J. T. A.; Silva, S. M. S. e; Moura, M. S. B.; Santos, D. C.; Silva, M. C.; Araújo, J. E. M. Indicadores de eficiência do uso da água e de nutrientes de clones de palma forrageira em condições de sequeiro no Semiárido brasileiro. Bragantia, v.73, p.184-191, 2014b. https://doi.org/10.1590/brag.2014.017

Taiz, L.; Zeiger, E. Fisiologia vegetal. 4.ed. Porto Alegre: Artmed, 2009. 819p. 